Portland State University

PDXScholar

Urban Studies and Planning Faculty

Nohad A. Toulan School of Urban Studies and

Publications and Presentations

Planning

$5-1-1996$

\title{
The Internationalization of Washington, D.C.
}

Carl Abbott

Portland State University, d3ca@pdx.edu

Follow this and additional works at: https://pdxscholar.library.pdx.edu/usp_fac

Part of the Urban Studies and Planning Commons

Let us know how access to this document benefits you.

\section{Citation Details}

Abbott, C. (1996). THE INTERNATIONALIZATION OF WASHINGTON, D.C. Urban Affairs Review, 31(5), 571-594.

This Article is brought to you for free and open access. It has been accepted for inclusion in Urban Studies and Planning Faculty Publications and Presentations by an authorized administrator of PDXScholar. Please contact us if we can make this document more accessible: pdxscholar@pdx.edu. 


\title{
The Internationalization of Washington, D.C.
}

\author{
Carl Abbott \\ School of Urban Studies and Planning \\ Portland State University \\ Portland, Oregon, USA
}

Prepublication version of article in Urban Affairs Review, 31 (May 1996) 


\title{
The Internationalization of Washington, D.C.
}

\begin{abstract}
The globalization of U.S. cities is attracting increasing theoretical and empirical attention. The author analyzes internationally oriented activities in metropolitan Washington, D.C, and demonstrates that the city's international roles are built directly on its historic function as a national city. Focusing on change over time, the author also shows that globalization is a stepwise process: several key periods of the expansion of international functions were followed by periods of gradual absorption. In comparative context, Washington supports arguments about the separability of international functions and shows the importance of historical development in determining the different ways in which cities interact with the world.
\end{abstract}


Self-appointed image makers have claimed a new identity for metropolitan Washington, D.C., in the last 15 years. The Washington Post has reported enthusiastically on the emergence of a newly internationalized city. The Greater Washington Board of Trade proclaimed Washington the place to be for firms engaged in international markets (Dudley and Nunes 1980b; Greater Washington Board of Trade 1987). An advertising campaign for a major bank recently characterized Washington as the most important city in the world. Geographers and regional planners have adapted the same terminology, describing Washington as a "world city" and an "internationalized city" with a "world role" and "international influence" (Knox 1987, 298; Fuller 1989, 118-19; Gottmann 1989, 64; Naylor 1992). The real estate press prefers the zippier phrase "world class" ("Reports say D.C. is a Strong Market, World-Class City" 1989).

At first glance, these claims may seem like the typical output of hot air vendors in editorial offices and economic development departments. In the U.S. urban system of the late twentieth century, it is New York, Los Angeles, and the San Francisco Bay metropolis that scholars have most often identified as international centers (Cohen 1981; Friedmann 1986; Castells 1989; Sassen 1991). In contrast, Washington's very reason for being is to serve the domestic need of national integration. As a neutral federal city, it houses the public decisionmaking apparatus established by the Constitution with the presumed intent of insulating that apparatus from the winds of sectionalism. Since the later nineteenth century, it has also developed into a national city with cultural institutions, sources of information, and symbols of national allegiance that have partially fulfilled the challenge of James Bryce $(1913,37)$ that it become "the embodiment of the majesty and stateliness of the whole nation." The range and variety of these national roles is measured by the Smithsonian Institution as a keeper of national cultural values, the United States Geological Survey as a source of useful public information, and the Lincoln Memorial as a focus for the emotions of nationalism and national identity (for 
recent work on Washington's symbolic functions, see Zelinsky 1988; Abbott 1990; Reps 1991; Fryd 1992; Boyer 1994; Lessoff 1994).

Although Washington's emerging international image contrasts with much of the city's historic character, the claims merit serious attention. As shaman and spin doctor both know, the act of naming has power in itself, often highlighting certain aspects of a phenomenon while ignoring others. Washington and Washingtonians have appropriated the international label at a time when many U.S. cities have become more directly and fully connected to the world through expanding international trade, investment flows, immigration, and even self-conscious municipal foreign policies (Hobbs 1994). Along with interconnected changes elsewhere around the world, this restructuring of economic activity and social patterns has generated a rich new literature on the character of major cities as centers of transnational organization and control. Urban internationalization of the sort being experienced by Washington and many other cities can involve any or all of three overlapping processes. One is the development of an economic base that depends heavily on foreign markets for locally produced goods and foreign customers for locally generated services such as transportation, finance, or consulting. This sort of international connection, of course, has long driven the growth of mercantile cities, ports, and European industrial cities (Vance 1977; Hohenberg and Lees 1985; Chase-Dunn 1985). Layered on these older patterns is a second and more recent process: an implosive concentration of the decision-making apparatus of global banks, multinational corporations, and other organizations with international reach. Related to both the old and new international economies has been a third process, the development of cosmopolitan communities marked by variety in ethnic and racial groups, languages, and cultural services. Such social and cultural heterogeneity can be seen as the consequence of traditional urban activities as gateways for trade and immigration (among dozens of examples, see Venice as described in Lane 1973 and McNeill 1974) and as vital social infrastructure for attracting and comforting a very new class of international 
information workers and transnational capitalists (Sklair 1991; Zukin 1991).

The recent literature on the emergence of world or global cities has been an effort to understand and contextualize the new centralization of world-scale decision making institutions. Driving much of the work is the desire to frame contemporary urbanization within the broad restructuring of the international division of labor during the 1970s and 1980s. Analysts such as Friedmann (1986), Feagin and Smith (1987), and Sassen (1991) have tried to identify new forces and outcomes within the long sweep of urban development. They see a reinforcing connection between dispersal of production and centralization of control: the merchants of old international cities traded things; the elite of new global cities coordinate other people's activities. The theoretical work takes off from efforts to understand the changing distribution of responsibilities within individual corporations (Hymer 1979) and quickly widens the focus to clusters of corporations with geographically proximate headquarters (Cohen 1981; Castells 1989). In Sassen's (1991) influential formulation, large complexes of corporate office and administrative offices call forth concentrations of producer services to supply specialized expertise and informational inputs. Although the logic of dispersal and concentration can apply at any scale from the single metropolitan area upward, world city theorists focus on the largest cities with global reach and describe a new urban system based on specialization in global finance and business services.

Without challenging the basic idea of a new informational hierarchy capped by global cities, after examining the internationalization of Washington, I see the need to modify several ancillary premises that are often associated with the model. First, the world-city thesis, by its rhetorical strategy and focus on new patterns, tends to ignore older or alternative forms of international connection for cities. Second, this focus on the restructuring of the global economy downplays the importance of historical endowments and the specifics of past economic and cultural roles for understanding how international roles may have evolved in a particular city. 
Instead, global cities are seen as detached from their regional and national situations and are treated as nodes in abstract information space (Feagin and Smith 1987; King 1990). Third, the model emphasizes private economic power, the influence of multinational corporations, and the sovereignty of mobile capital to the substantial exclusion of state-based activities and influence.

Washington fits none of these secondary premises very closely. Like a number of other U.S. cities, it has developed substantial international roles apart from the corporate and finance complex that now drives a global city such as New York. In pursuing this point, the following case study provides historical justification for the findings of Markusen and Gwiasda (1994) about Washington's importance as a node for information production and manipulation distinct from New York. The analysis also supports their argument about the separability of different international functions and the emphasus of related work that finds multiple trajectories toward internationalization (Abbott 1993). As Markusen and Gwiasda show, cities display different layerings and mixes of international activities. They argue specifically that the locational patterns of trade, government, and education are highly independent of other activities and that finance, research and development, culture, and health and social welfare services are moderately independent. Washington's most important international functions are those with low linkages (government, education) or moderate linkages (culture, research), in contrast to the strongly linked financial services that characterize New York. This case study thus contributes to a long-established literature founded on the argument that a wide range of cities and city types can interact with the world within complex lateral networks of specialized roles (McKenzie 1927).

In Washington, moreover, what is international is national, based on an elaboration of domestic political and cultural functions. An assessment of Washington against a variety of measures of globalization establishes that the city's international functions are built directly on 
its historic role as the seat of government. Its international sector has developed and extended its national capital functions such as the federal research establishment, national cultural institutions, administrative agencies, trade associations, and public interest organizations (Hamer and Company Associates 1958; Drennan 1992). In these ways, the analysis parallels Hill and Fujita's (1995) description of the global reach of Tokyo as deeply dependent on that city's concentration of state power. Washington's international roles are expansions and elaborations of the same sorts of functions that it performs on the national scene rather than disconnected departures from these functions.

Finally, what is new in Washington is also old. The city's development history supports those global city theorists who refine the broad model by emphasizing the importance of understanding change over time (Markusen and Gwiasda 1994) and exploring each city's "rootedness in . . . history, institutions, culture, and politics" (Friedmann 1993, 20). The U.S.

national metropolis has expanded its international roles by degrees. The decades around 1900, the 1940s, and the 1970s were key periods for the addition or expansion of international functions, followed in each case by a period of absorption involving gradual changes in local culture and tone of life. At every step, control and coordination functions were the leading sectors, followed by new direct services for foreign markets. In turn, these functional changes have led cultural change, with the metropolitan community as a social system responding and adapting to new international roles.

\section{STAGE ONE: 1880-1940}

The origins of a modern globally connected Washington date to the 1880s and the policies of Secretary of State James G. Blaine, who convened an Inter-American Conference in Washington in 1889-1890. The 10 U.S. delegates and 17 Latin American delegates created the International Union of American Republics, which evolved into the Pan American Union (1910) 
and then the Organization of American States (1948). Under the aegis of the International Union and the financial sponsorship of the United States, the small Commercial Bureau of the American Republics began to gather and publish data on customs regulations, products, and markets. Added in 1902 was a Pan American Sanitary Bureau (now the Pan American Health Organization) with its own Washington-based secretariat of 7 persons (Thomas and Thomas 1963, 12-15; Inman 1965, 33-59).

The late nineteenth and early twentieth centuries were also the first significant era of international conventions and conferences. The rapidly increasing speed, safety, and comfort of crossing the Atlantic after 1870 constituted a transportation revolution not too different in effect from that of jet airplanes after 1960. The upper class tourism that Henry James and Edith Wharton described in their novels was mirrored by the travels of government officials and scientists to attend Washington meetings, such as an International Medical Congress (1887), International Marine Conference (1889), International Geological Congress (1891), International Women Suffrage Conference (1902), or International Congress on Hygiene and Demography (1912). Local economic boosters (Washington, D.C., with Its Points of Interest Illustrated 1894, 6) began to claim that "the foreigner turns his face towards Washington," for here are meetings year by year in increasing variety and numbers, visitors from every corner of the continent, and from every country on the face of the globe, and countless popular assemblies, conventions, and representative congresses of all creeds, professions and nationalities.

Notwithstanding these activities, Washington's international roles remained narrow. The international tourism described above was an elite activity rather than a mass phenomenon, with meetings attracted by Washington's scientific establishment or by the symbolism of its political role. European visitors sometimes found the city pleasant and sometimes boring, but they never confused it with a major world capital (Bryce 1912, 2:855-61). Only a handful of Washington- 
based organizations or businesses identified themselves as international in orientation or function in 1900 and fewer than 50 even after the upheavals of World War I (see Table 1). The strongest focus of such organizations was Latin America, because the early twentieth-century United States asserted hemispheric rather than global leadership.

\section{Place Table 1 about here}

With broader diplomatic or military roles still small, the city's cosmopolitanism remained limited. One caustic observer as late as 1920 thought that the main function of the diplomatic corps was to teach Washingtonians the art of dining out (Rhodes 1920, 124; Hurd 1948, 287). European diplomats treated Washington as a minor capital. British representatives used their hill allowance--compensation for posting on the subtropical Potomac--to join European colleagues in Newport or New York as often as business allowed. The leaders of Washington's high society confirmed the city's provinciality by going atwitter for nearly a full year before a brief visit by King George VI of the United Kingdom in 1939 (Briggs 1906, 164; Lombard 1941, 3-4; Brinkley 1988, 32, 46).

\section{STAGE TWO: 1940-1970}

World War II cracked open Washington's insularity. In 1942-1943, Washington joined and then supplanted London as the decision center for the global war against the Axis powers. As the command post for the world's most far-flung military enterprise, it seemed to many observers to have emerged as the "first city of the world" (Hurd 1948, 263; also see Reston 1941, Henrickson 1983, 135-36). More than 3000 British and Commonwealth businessmen, military officers, and diplomats staffed organizations such as the British Shipping Mission, Munitions Assignment Board, and Combined Raw Materials Board in commandeered hotels and apartment buildings. Their Latin American counterparts staffed the new Inter American Defense Board, one of many wartime organizations that survived into the Cold War (Stevens 1943, 319-23; 
Brinkley 1988, 50). The number of diplomatic officials assigned to Washington doubled from 1940 to 1945 . It doubled again from 1945 to 1956 as the internationalization of peacetime foreign policy during the Truman administration attracted a greatly expanded diplomatic corps (Robert R. Nathan Associates 1978). ${ }^{1}$

Just as important for Washington's emergent role as a venue for international decisions was its campaign for the International Bank for Reconstruction and Development (World Bank) and the closely associated International Monetary Fund (IMF), both of which opened for business in 1946. The Washington business community, working through the Board of Trade, helped the Roosevelt and Truman administrations fight the New York banking establishment in a two-stage battle for the new financial institutions that had been designed at the Bretton Woods conference in 1944. New York business leaders first opposed the authorizing legislation that created an alternative focus for world finance. Losing that issue, Wall Street interests then pushed New York over Washington for the headquarters of the World Bank and IMF. The arguments for Washington emphasized the intergovernmental character of the new agencies and the need for easy communication through Washington's diplomatic community. The desire of New Deal Democrats to loosen the grip of New York banks on the nation's international economic policy swayed the decision in favor of Washington (Meyer 1946; "New Bank Pleases Financiers" 1946; Blum 1967, 427-36; Gardner 1956, 265).

The tenure of Eugene Meyer, the first World Bank president, summed up the partial character of Washington's victory. An investment banker who made a fortune in New York, Meyer became deeply involved in national economic policy with World War I and transferred his base of business activity to Washington in 1933 with the purchase of the Washington Post. Under his chairmanship, the Board of Trade's Postwar Planning Committee in 1945-1946 emphasized Washington's potential as a "world capital" with "scores of new agencies, private, semi-public, governmental, and international" (Washington Board of Trade 1945, 1). Meyer's 
appointment to head the World Bank thus represented a declaration of financial independence by both the city and the federal government. Within the year, however, it was clear that the World Bank could not function without supplementing capital assessments on member nations with funds channeled through New York banks. Meyer's replacement by Wall Street lawyer John McCloy late in 1946 ended Washington's brief victory. The headquarters and the jobs remained on $\mathrm{H}$ Street in a building originally intended for the State Department, but the power stayed in New York (Gardner 1956, 298-99).

Postwar Washington faced additional U.S. competition as a world political center. San Francisco and New York continued to house the largest clusters of bankers and lawyers knowledgeable about international trade and global concerns (Cohen 1981, 287-315). Both cities played the key roles in the formation of the United Nations (UN). Along with Boston, they competed for the permanent UN headquarters. Its location in Manhattan attracted dozens of related organizations and experts dealing in international affairs to New York rather than to Washington.

In the same era that European empires were beginning to unravel, racial segregation in the District of Columbia and adjacent states undercut Washington's attractiveness for multinational organizations. The problems of segregation derailed a bid for the UN headquarters from the state of Virginia ("Virginians Seeking UNO Site" 1946), and the reduction of racial restrictions in the District of Columbia and surrounding suburbs was an important part of the nation's Cold War strategy. Nevertheless, cultural adaptation again lagged behind functional changes. From the 1947-1948 reports of the President's Committee on Civil Rights and the National Committee on Segregation in the Nation's Capital to the collapse of Virginia's program of massive resistance to school integration in 1959, it took more than a decade to replace Washington's southern system of racial relations with the formally open northern system that was more welcoming to African and Asian officials (Green 1967; Wiggins 1966; Muse 1961). 
There is little published evidence that Washingtonians thought deeply about changes in the city's international role in the first two decades after World War II. An early 1960s guidebook description of Washington as "the world city of our time" was an isolated case (Moyers 1971, 326). The 15 translation and interpreting services listed in the 1950 telephone directory grew to only 20 in 1960, scarcely the sign of a flood of international visitors and business. A city in which the 1965 opening of the so-called International Safeway (a grocery store) at 1110 F Street NW was a cultural event had weak claims on membership in the exclusive circle of global cities.

The Board of Trade's fruitless campaign to make Washington rather than New York the site for the 1964 world's fair displayed the strengths and weaknesses of postwar Washington as an international center. New Yorkers confidently argued the merits of their city before President Eisenhower's site selection commission in 1959. Addressing the President's Commission on the World's Fair, Mayor Robert Wagner, Senator Jacob Javits, and public works czar Robert Moses variously described their city as the world capital, the headquarters of the world, a world-wide market place, and the world's leading city. (Washington Board of Trade Papers 1959). Washington's advocates, in contrast, could only counter with "Capital of the Free World" and emphasize the intangible attractions of Washington to U.S. citizens. Their strategists played on Washington's role as the national city and recruited letters of endorsement from mayors, members of Congress, and governors of such land-locked states as Arkansas and North Dakota (Press 1959; "A Fair for Washington" 1959). New Yorkers touted their city's international functions and claimed the fair, leaving Washingtonians the consolation of their city's national and international symbolism.

\section{STAGE THREE: 1970-1995}

The mid-1970s and 1980s, in contrast, added greater substance to international claims. 
The internationalization of Washington became a new staple of public discussion. Business leaders now argued that Washington was growing into a world business city. Civic organizations found it reasonable to assert that Washington was a global political and financial coordinating center with a growing list of foreign businesses. The Government of the District of Columbia $(1983,81)$ urged business executives to consider the city's value as a "world center of research and information." Congressman Charles Diggs, Jr., the chair of the House Committee on the District of Columbia, opened hearings in 1977 by describing Washington's potential to be "one of the really great cities of the world . . . the Nation's Capital, a federal City, and international city" (U.S. House 1977, 1; see also Carr 1978; Tydings 1978; Shidler 1980, 13-14).

The burst of rhetoric reflected a new stage in Washington's engagement with the world economy that coincided with massive corporate and financial restructuring throughout the world. Where the previous stage had depended directly on the growing diplomatic and military presence of the United States in the world, the developments in the 1970s and 1980s were tied as well to the city's increasing importance and diversity as a national information broker. The overall shift of the U.S. economy toward information and services drove the explosive growth that pushed Washington from eighteenth place among U.S. metropolitan areas in 1930 to eighth place in 1990. In the process, Washington's specialization in national defense and in the prominent information industries of politics, administration, research, education, and cultural tourism allowed boosters such as the Washington/Baltimore Regional Association to claim the title of "information capital of the world" (Goldstein 1989).

Most obviously, Washington consolidated its position as a central place for the functions of informal imperialism. It was the center for the coordination of economic policy, diplomatic initiatives, and a vast system of military bases and alliances. If the hundreds of U.S. embassies, consulates, and military bases can be viewed as the dispersed production sites for global influence, the Pentagon and State Department buildings were the federal equivalent of Wall 
Street office towers. By the early 1970s, Washington area employment in international governmental agencies ranged from hundreds of workers with the Arms Control and Disarmament Agency or the Council for International Economic Policy to thousands with the United States Information Agency and tens of thousands with the Department of Defense (Robert R. Nathan Associates 1978).

In the international as well as the national arena, a vast private and semipublic information industry has grown up around this set of governmental agencies. In this light, it is important to note that much of the growth of Washington's domestic information industry predates the international turn by only a decade or two. Despite a proliferation of pressure groups to stand watch around the White House and Capitol during the New Deal, Washington as late as 1959 housed only 15\% of the organizations listed in the Encyclopedia of American Associations, far behind New York at 33\% and just ahead of Chicago at 11\% (Daniels 1946, 144-45; Lieberson and Allen 1963). Between the mid-1960s and the mid-1970s, however, Washington's lower rents and accessibility to government decision makers and regulators edged it past New York with a quarter of the country's trade associations. By 1987, the continuing importance of close contact with federal regulators, procurement officers, and congressional committees had pushed the Washington area share of national organizational headquarters above 30\%, making associations and trade groups the area's third largest industry (Jordan 1987). Between 1950 and 1980, Washington also surged from fourteenth place to third place in the number of large and multioffice law firms (Lynch and Meyer 1992). Its growing role as a decision center for the domestic economy can also be approximated by the relative importance of employment in the census category of central administrative offices and auxiliaries for multiestablishment firms in mining, construction, manufacturing, trade, and service industries. Between 1954 and 1972, metropolitan Washington's 320\% increase in such jobs trailed only Boston, Houston, Denver, and Atlanta (Armstrong 1979, 61-93). During the following period 
(1974-1985) Washington's 90\% growth in producer services employment matched such growth in metropolitan Boston, Los Angeles, and San Francisco and far exceeded that in New York (Markusen and Gwiasda 1994).

Growth in the number of Washington-based international governmental and international nongovernmental organizations has followed the increase of domestic association offices and benefited from availability of a specialized pool of association staff and executives. Since World War II, such international organizations have spread widely from their European homeland where the rules and forms of diplomacy were created. Their worldwide numbers are now so great that the Yearbook of International Organizations divides them among eight different categories. As late as 1962, Washington housed the headquarters or regional office of only 47 international organizations compared with 164 for New York, a ratio of 3.5 to 1 in favor of the economic capital (Union of International Associations 1962). As of 1985, in contrast, Washington had the principle secretariat of 462 such organizations and a secondary or regional secretariat of 45 more, largely closing the gap on New York, whose total of 701 gave it only a 1.4 to 1 edge. The list of such organizations ranges from specialized academic societies, such as the German Historical Institute, to giants such as the World Bank or Organization of American States. Washington-based employment in many of these major multinational organizations grew substantially in the later 1960s and 1970s, doubling or even tripling in some cases (Robert R. Nathan Associates 1978, 18-41; Fuller 1989, 115). In total numbers, Washington passed such historic centers as Zurich and Geneva to rank sixth among world cities. Its lead over Mexico City doubled. It counted 8 times as many secretariats as did Montreal and 10 times the number in Toronto (Union of International Associations 1985).

The proliferation of Washington's international organizations accompanied an increasing importance for Washington as a generator of foreign policy ideas. During the early and middle decades of the twentieth century, U.S. foreign policy largely followed the ideas of a New York- 
based elite that expressed itself through the Council on Foreign Relations and through a series of Secretaries of State: Elihu Root, Charles Evans Hughes, Henry Stimson, Dean Acheson, John Foster Dulles. Beginning in the 1960s, however, Washington-based institutions began to rival the Council on Foreign Relations as centers of foreign policy expertise. Particularly important were think tanks that had close ties to the defense establishment and to southern and western defense contractors (Johnson 1993, 385-86; Kurth 1993; Shefter 1993). The new importance of Washington as a source of foreign policy opinion was thus closely associated with the emergence of its intellectual apparatus for articulating a neoconservative domestic agenda, sharing the same ideological bent and similar sources of funding (Ricci 1993). It can also be read as another stage in the long contest between Europe-firsters and Asia-firsters that underlay midcentury policy debates.

In the 1980s, international corporations began to follow governmental and nonprofit organizations. Here too, the same factors that have made Washington a national information center have also worked on the wider scale of corporate activity (Washington Board of Trade 1986). For U.S. firms with international interests, argue the boosters (Greater Washington Board of Trade 1987), greater Washington offers a community of worldwide investment and trade organizations that create an entree to the far corners of the earth. For international firms, Washington offers the U. S. base of operations close to the government regulatory agencies which oversee import/export trade.

The latter point has apparently been convincing, because the local business press reports that more and more European companies have been establishing their main U.S. offices in Washington rather than New York (Isaac 1990). A prominent business consulting firm ranked Washington fourth among 60 world cities as a desirable location for international headquarters, following Singapore, London, and New York ("Singapore Ranked Top City for International 
Headquarters" 1990).

Behind the boosterism, the particular attraction of Washington for both domestic and foreign firms is the ease of monitoring the rapidly changing U.S. policy environment, lobbying for access to domestic markets, and maintaining contact with state governments, national business and trade associations, and international organizations. In this sphere, Washington's governmental establishment weakly mirrors the attractive power of Tokyo's government sector

for Japanese and foreign firms, with the difference in intensity reflecting the much more detailed involvement of the Japanese state in economic affairs (Hill and Fujita 1995). Among U.S. corporations, the major move was Mobil Corporation's relocation from New York to northern Virginia in search of higher quality of life and easier international air connections (Lawrence 1989). The number of foreign companies with representation in Washington increased from 580 to 950 between 1979 and 1987, including three-fourths of the world's reputedly largest corporations (Greater Washington Board of Trade 1987). Japan, which accounts for 15\% of the represented firms, spends an estimated \$100 million annually on Washington lobbyists, attorneys, political advisors, and corporate offices (Averyt 1990; Weiss 1990; Choate 1988, 6063; Fessler 1990, 972-75; Sands 1988).

Education, research, and consulting have also emerged as in recent decades as important components of the larger category of producer services (Drennan 1992; Sassen 1991, 1994). International consulting is most obvious in the activities of the Washington offices of multinational accounting/business management companies. Hundreds of smaller professional firms form a substantial export sector that is invisible in census and trade data at the metropolitan scale. In contrast, it is easy to document the growing numbers of foreign college and university students in the Washington area, from fewer than 200 in 1938-1939 to 1000 in 1949-1950, 3500 by $1963-1964$, and 16,000 in the middle 1990 s. $^{2}$

Students, of course, can be viewed as a very specialized type of tourist. Long-distance 
tourism has become mass-market in the last two decades with the help of jumbo jets and First World affluence. Europeans vacation in the Canaries, Japanese take weekends in Singapore and Honolulu, Venezuelans shop in Miami. Washington has been a major destination for the rapidly growing numbers of foreign visitors to the United States, whose spending in this country first exceeded spending by U.S. tourists abroad in 1989 (Zelinsky 1990). According to a survey of air travelers administered by the U.S. Travel and Tourism Administration, the city's 1.5 million foreign visitors in 1988 amounted to $10 \%$ of all such travelers to the United States, placing the city behind New York, Los Angeles, San Francisco, and Honolulu. The capital city has a special role, of course, as host for officially sponsored junketeers. Another of its special functions is as one of the top dozen world cities for international conventions and meetings. Although data are sporadic and incomplete, Washington and New York appear to have shared a roughly equal and growing number of international meetings in the 1970s and 1980s (Washington Convention and Visitors Bureau 1972; Goss 1975; Gappert 1989). This is a function that benefits from the facilities developed for a similar role as a national convention city and continues on a vastly expanded scale its earliest international roles from the nineteenth century.

In the 1980s, daily life in Washington increasingly began to support the international tone of its economy. More than 150 nations were represented by two and a half thousand diplomatic officers; hundreds of other foreign nationals worked for multigovernmental agencies.

Newspaper stories described foreign real estate investment, multilingualism, and even the number of Washingtonians holding passports (twice the proportion as Detroit or Dallas) (Dudley and Nunes 1980b; McGrath and Means 1980; Washington Post Retail Memo and Sales Planner 1984; Pressley 1992; Henrikson 1983, 142). The erosion of Washington's cultural insularity made the city more compatible and attractive for foreign business and diplomatic families and global infocrats with strong ideas about suitable cityscapes and societies (Knox 1991). Through the 1960s, according to figures maintained by the State Department Office of Protocol, the 
number of diplomatic family members roughly matched the number of diplomats; in the 1970s the number of family members rapidly doubled the count of diplomats (Dudley and Nunes 1980a; Robert A. Nathan Associates 1978, Table 20).

A new cosmopolitanism on the streets and neighborhoods now supplemented the sheltered social life of embassy row. Fourteen percent of metropolitan area residents were foreign born by 1990, more than tripling 1960's proportion of 4\% and placing Washington in the high range of immigrant population for U.S. metropolitan areas. ${ }^{3}$ Hispanic and Asian-American populations roughly doubled in the 1980 s alone. At the start of the 1990s, 36,000 immigrants per year were listing Washington as their metropolitan area of intended residence (U.S. Department of Commerce 1993). ${ }^{4}$

One summary indicator of Washington's growing global connectivity is the names chosen by its businesses and organizations. Scholars have frequently used such data to measure U.S. regional consciousness and determine, for example, that Topekans feel more midwestern than western and Houstonians more southwestern than southern. Washingtonians, such studies suggest, are confused about their place in the U.S. scene, associating themselves strongly with neither the East nor the South (Zelinsky 1980; Reed 1976). An examination of Washington as an international city, however, suggests the value of rephrasing the question to carry beyond continental boundaries (see Table 1). The 1991 telephone directory for metropolitan Washington contained 1260 listings that started with terms such as world, world-wide, global, or international. Only 845 listings started with relevant regional terms such as Atlantic, mid-states, eastern, or southern. Indeed, Washington joins Miami-Fort Lauderdale and New York as one of three U.S. metropolitan areas where "international" listings outnumber those with a regional reference. $^{5}$

City directories and phone books also confirm the timing of Washington's internationalization. From 1900 to 1940, listings with national, international, and regional 
terminology grew at essentially the same rate. After 1940, in contrast, international listings began to grow at twice the pace of regional terms and passed them in total number in the mid1960s. They grew at two and a half times the rate of national terms over the same 1940-1990 period. The telephone books--those essential tools of the information age--indicate that late twentieth-century Washington is situated not only in a particular part of the United States but also within the global networks of the transactional economy.

\section{INTERNATIONAL WASHINGTON AND THE POWER OF HISTORY}

The evolution of Washington's international roles can be summarized by the character of successive organizations. The Pan American Union, the most important institution of the first stage, began with limited scope and aims in the 1890s and grew slowly. In contrast, the World Bank represents the ways in which Washington's expanding international roles at midcentury were tied to military and diplomatic leadership of the western alliance during World War II and the Cold War. For the most recent stage, the combination and contrast of Mobil Corporation and Georgetown University's Center for Strategic and International Studies suggest the diversification of Washington's role as international decision center.

As the broader comparisons in Table 2 indicate, however, it is important to balance the local enthusiasm with a reminder of the wide gaps in Washington's international presence. ${ }^{6}$ Its new cosmopolitanism is still limited in comparison to immigrant gateway cities such as Los Angeles, New York, or Miami. It is neither an international port nor a major center for multinational corporate decisions; only one member of Forbes magazine's list "The 100 largest U.S. Multinationals" (1993) is headquartered in the Washington area. Unlike Seattle or Chicago, Washington is not a manufacturing city that sells to world markets (Mehl 1987). Neither is it a leader in international banking, for its historic lack of manufacturing and foreign commerce limited Washington banks to real estate loans and left the local responsibility for international 
finance to nearby Baltimore (Noyelle 1985). This selective specialization supports the theoretical arguments for the separability of international functions and the distinctiveness of globalization trajectories from city to city.

\section{Place Table 2 about here}

The recent economic history of Washington and its contrasts with other cities supports an important analytical distinction between a handful of world cities that structure and dominate a hierarchy of corporate and financial power and a larger number of international cities. A small number of metropolitan regions house the elites of world capitalism--bankers, multinational executives, business consultants, globe-trotting artists. They also retain important roles as manufacturers and traders in world markets. Washington boosters such as congressional delegate Eleanor Holmes Norton may feel no embarrassment in grouping Washington as a peer of world-city London or Paris (Spayd 1992), but it is unlikely that Londoners or Parisians agree. Indeed, Washington seldom appears on scholarly lists of likely global cities, presumably because it lacks the key control institutions for private capital.

At the same time, however, the development of Washington shows the value of examining the wide variety of ways that North American cities meet and have met the world. As is also true in Europe, the roster of substantially internationalized cities is far larger than the short list of global cities (Kunzman and Wegener 1991; Parkinson 1991). U.S. cities have numerous direct connections to global flows of goods, people, and information that are not channeled through New York or Los Angeles and have promoted and developed these connections in historically distinct ways. Houston is a port and production center that interacts directly with the world of petroleum producers and has gradually substituted sales of expertise for direct sales of petroleum products (Feagin 1988). Seattle is part of a land bridge between the Pacific and Atlantic economies and now a partner with Vancouver in trying to redefine the Pacific Northwest as an internationalized economic region. The arrival of a Cuban middle class 
in the 1960s triggered the internationalization of Miami by providing a skilled labor pool for corporate offices and international banks (Sassen and Portes 1993; Portes and Stepick 1993). Atlanta has developed international roles because of its good access to sunbelt markets and factory sites for foreign corporations, because of active promotion of an international identity (White and Crimmins 1978), and because of the entrepreneurial accident of the location of the Cable News Network.

In important ways, Washington is an anomaly that requires rethinking several ancillary premises of world city theory and reminds us of the richness of urban experience. Washington is not a global city that directly rivals New York or Los Angeles. Instead, the national metropolis has built its increasingly rich, numerous, and complex international roles and connections on its concentration of public-sector rather than private-sector activities, on bureaus rather than board rooms. As a specialized information city, Washington has followed a trajectory perhaps most similar to that of Honolulu, which has deliberately tried to build international activities on the government, research, and tourism sectors of its economy (Heenan 1977). In this light, Washington's growing but still limited international roles are vulnerable less to competition from New York than to a new isolationism and conservative ideology that sees a proud and ambitious Washington as a symbol of oppressive government rather than national achievement (Cattani 1990).

Washington is also a city that has remained essentially national at the same time that it has taken on international roles. Far from delinking from its roles as a national cultural and administrative center, Washington has directly exploited such roles as a powerful magnet for private sector producer services. It is an international city because it articulates aspects of national character and power and mediates between a large and prosperous nation and a set of constantly changing international relationships that require careful and flexible management. Its international roles are elaborations of its history as a national capital much more than responses 
to radical economic restructuring.

Although it is a public information capital rather than a corporate control center, the Washington example confirms the basic dynamic of dispersal and centralization. State power and public information are centralized forces that attract a complex of private sector activities in ways similar to the attractions of concentrated financial power. In this light, the federal government can be understood as a producer service that is an important input for domestic and foreign corporations (see Hill and Fujita 1995 for Tokyo parallels). Government itself, moreover, involved as it is with the projection of economic and military power and diplomatic influence, is an activity with internationally dispersed production sites that require central coordination. Washington's role as a command post for Pax Americana thus parallels London's earlier role as an imperial capital (King 1990). The new international Washington, in short, is the old national city projected on a wider screen. 


\section{NOTES}

1. The count of ambassadors, ministers, first secretaries, and other diplomats worthy of special social attention tripled during the same period (Hagner 1940; Shaw 1956).

2. The numbers I report from these sources are the totals for the District of Columbia plus one-third of the totals for Maryland (as an estimate of foreign students at the main University of Maryland campus at College Park) (Kelley and Eckert 1942; Strong 1951; Rice and Mason 1966). The figure of 16,000 for the 1990s is derived from data in the Chronicle of Higher Education, November 10, 1995, and includes all listed institutions in the metropolitan area.

3. The $14 \%$ figure is for the same territory included in the 1980 metropolitan area. By 1990, the addition of three outlying counties led to an overall figure of $13.2 \%$ within expanded boundaries.

4. In turn, economic and personal connections appear to have driven improvements in international air connections. Dulles Airport, opened in 1963 to serve as an international hub, remained underutilized until the mid-1980s. In the early 1990s, however, booming growth of international travel through both Dulles and Baltimore/Washington airports pushed Washington into fifth place among U.S. cities for international air travel. Data from Metropolitan Washington Airports Authority (1994) and Leepson (1992).

5. In making comparisons among cities, I have assumed that the various outlets for the International House of Pancakes and similar uses of the terms cancel each other out. More problematic is the fact that the methodology does not pick up national terms that may represent either business-institutional connections (Korea Society) or significant immigrant communities (Korean Methodist Church). 
6. Table 2 includes the six cities compared by Markusen and Gwiasda (1994) plus three major sunbelt cities. 


\section{REFERENCES}

Abbott. C. 1990. Dimensions of regional change in Washington, D.C. American Historical Review 95 (5): 1367-94.

-----. 1993. Through flight to Tokyo: sunbelt cities in the new world economy, 1960-1990. In

Urban policy in twentieth century America, edited by A. R. Hirsch and R. Mohl, 193-212. New Brunswick, NJ: Rutgers Univ. Press.

Armstrong, R. B. 1979. National trends in office construction, employment and headquarter location in U.S. metropolitan areas. In Spatial patterns of office growth and location, edited by P. W. Daniels, 61-93. Chichester, UK: J. Wiley and Sons.

Averyt, W. F. 1990. Managing public policy abroad: Foreign corporate representation in Washington. Columbia Journal of World Business 25 (3): 32-41.

Blum, J. M. 1967. From the Morganthau diaries, Vol. 3; Years of war, 1941-1945. Boston: Houghton Mifflin.

Boyer, M. C. 1994. The city of collective memory: Its historical imagery and architectural entertainments. Cambridge, MA: MIT Press.

Briggs, E. E. 1906. The Olivia letters. New York: Neale Publishing.

Brinkley, D. 1988. Washington goes to war. New York: Knopf.

Bryce, J. 1912. The American commonwealth, rev. ed. New York: Macmillan.

-----. 1913. The nation's capital. Washington, DC: Byron S. Adams.

Carr, O. T. 1978. Transcript of remarks at inauguration of Mayor Marion Barry, 3 January, in Washington Board of Trade papers, George Washington University Special Collections, Washington, DC. 
Castells, M. 1989. The informational city. Oxford, ENG: Basil Blackwell.

Cattani, R. J. 1990. Washington at the global frontier. Christian Science Monitor, 19

December, 15.

Chase-Dunn, C. K. 1985. The system of world cities, A.D. 800-1975. In Urbanization in the world-economy, edited by M. Timberlake, 269-92. New York: Academic Press.

Choate, P. 1988. Foreign capital PACs a punch. Across the board 25 (10): 60-63.

Cohen, R. B. 1981. The new international division of labor, multinational corporations, and urban hierarchy. In Urbanization and urban planning in capitalist society, edited by M. Dear and A. J. Scott, 287-315. New York: Methuen.

Daniels, J. 1946. Frontier on the Potomac. New York: Macmillan.

Drennan, M. P. 1992. Gateway cities: The metropolitan sources of US producer services exports. Urban Studies 29 (2): 217-35.

Dudley, C., and D. Nunes. 1980a. DC provides refuge for world's rich. Washington Post, 4 February, A:1

-----. 1980b. Washington: the new international city. Washington Post, 3 February, A:1. A fair for Washington. 1959. Washington Post, 15 August, A:8.

Feagin, J. R. 1988. Free enterprise city. New Brunswick, NJ: Rutgers Univ. Press.

Feagin, J. R., and M. P. Smith. 1987. Cities and the new international division of labor: an overview. In The capitalist city: Global restructuring and community politics, edited by M. P. Smith and J. R. Feagin, 3-34. Oxford, ENG: Basil Blackwell.

Fessler, P. 1990. Targeting Japan: Do lobbying dollars shape the U. S. trade debate?

Congressional Quarterly Weekly 48 (March 31): 972-75.

Friedmann, J. 1986. The world city hypothesis. Development and Change 17 (1): 69-83.

-----. 1993. Where we stand: a decade of world city research. Report D 9304, Los Angeles:

Graduate School of Architecture and Urban Planning, University of California. 
Fryd, V. G. 1992. Art and empire: The politics of ethnicity in the United States Capitol. New Haven, CT: Yale Univ. Press.

Fuller, S. 1989. The internationalization of the Washington, D.C., area economy. In Cities in a global society, edited by R. V. Knight and G. Gappert, 108-19. Newbury Park, CA: Sage. Gappert, G. 1989. A management perspective on cities in a changing global environment. In Cities in a global society, edited by R. V. Knight and G. Gappert, 312-25. Newbury Park, CA: Sage.

Gardner, R. N. 1956. Sterling-dollar diplomacy. Oxford, ENG: Clarendon Press.

Goldstein, S. 1989. Regional group upbeat about 'common' market. Washington Times, 3 May, $\mathrm{C}: 1$.

Goss, K. N. 1975. The market for international congresses. Washington, DC: U.S. Travel Service, Department of Commerce.

Gottmann, J. 1989. What are cities becoming the centers of? Sorting out the possibilities. In Cities in a global society, edited by R. V. Knight and G. Gappert, 58-67. Newbury Park, CA: Sage.

Government of the District of Columbia. 1983. Comprehensive plan for the national capital.

Washington, DC: Author.

Greater Washington Board of Trade. 1987. A capital link. Washington, DC: Author

Green, C. M. 1967. The secret city: A history of race relations in the nation's capital. Princeton, NJ: Princeton Univ. Press.

Hagner, H. R., ed. 1940. Social list of Washington, D.C. Washington, DC: Author.

Hamer and Company Associates. 1958. Economic development in the Washington area, staff study for the Joint Committee on Washington Area Problems, Congress of the United States. Washington, DC: Government Printing Office.

Heenan, D. A. 1977. Global cities of tomorrow. Harvard Business Review 55 (3): 79-92. 
Henrikson, A. K. 1983. A small, cozy town, global in scope: Washington, DC. Ekistics 50 (299): 123-45.

Hill, R. C., and K. Fujita. 1995. Osaka's Tokyo problem. International Journal of Urban and Regional Research 19 (2): 181-94.

Hobbs, H. H. 1994. City hall goes abroad: The foreign policy of local politics. Thousand Oaks, CA: Sage.

Hohenberg, P., and L. H. Lees. 1985. The Making of urban Europe, 1000-1950. Cambridge, MA: Harvard Univ. Press.

Hurd, C. 1948. Washington cavalcade. New York: E. P. Dutton.

Hymer, S. H. 1979. The multinational corporation: A radical approach. Cambridge, ENG:

Cambridge Univ. Press.

Inman, S. G. 1965. Inter-American conferences 1826-1954: History and problems. Washington:

University Press of Washington, D.C.

Isaac, D. 1990. D.C. becomes choice of more European firms. Washington Business Journal, 15 January, 1.

Johnson, D. A. 1993. World city/capital city: New York in the changing global setting. In

Capital cities: international perspectives, edited by J. Taylor, J. G. Lengelle, and C. Andrew, 377-98. Ottawa, ONT: Carleton Univ. Press.

Jordan, M. 1987. Trade groups flock to region. Washington Post, 19 February, C:1.

Kelley, F. J., and R. E. Eckert. 1945. Residence and migration of college students, 1938-39.

Washington, DC: U. S. Office of Education.

King, A. D. 1990. Global cities: Post imperialism and the internationalization of London.

London: Routledge.

Knox, P. 1987. The Washington metropolitan area. Cities 4 (4): 290-98.

-----. 1991. The restless urban landscape: economic and sociocultural change and the 
transformation of Washington, D.C. Annals of the Association of American Geographers 81 (2): 181-209.

Kunzman, K., and M. Wegener. 1991. The pattern of urbanization in Western Europe," Ekistics 58 (350-351): 282-91.

Kurth, J. R. 1993. Between Europe and America: The New York foreign policy elite. In Capital of the American century: The national and international influence of New York City, edited by M. Shefter, 71-94. New York: Russell Sage Foundation.

Lane, F. C. 1973. Venice: A Maritime Republic. Baltimore, MD: Johns Hopkins Univ. Press. Lawrence, B. H. 1989. Mobil makes its move. Washington Post, 18 September, WBIZ:1. Leepson, M. 1992. Meetings and travel: Washington's airports. Regardie's Magazine 12 (AprilMay): 57-74.

Lessoff, A. 1994. The nation and its city: Politics, 'corruption,' and progress in Washington, D.C., 1861-1902. Baltimore, MD: Johns Hopkins Univ. Press.

Lieberson, S., and I. L. Allen, Jr. 1963. Location of national headquarters of voluntary associations. Administrative Science Quarterly 8 (4): 316-38.

Lombard, H. 1941. Washington waltz: Diplomatic people and policies. New York: Knopf. Lynch, J., and D. R. Meyer. 1992. Dynamics of the U.S. system of cities, 1950-1980: The impact of the large corporate law firms. Urban Affairs Quarterly 28 (1): 38-68.

Markusen, A., and V. Gwiasda. 1994. Multipolarity and the layering of functions in world cities: New York City's struggle to stay on top. International Journal of Urban and Regional Research 18 (2): 167-93.

McGrath, P., and H. Means. 1980. How Washington became a real city. The Washingtonian 16 (10): 130-60.

McKenzie, R. D. 1927. The concept of dominance and world-organization. American Journal of Sociology 33 (1): 28-42. 
McNeill, W. H. 1974. Venice: The hinge of Europe. Chicago: Univ. of Chicago Press. Mehl, G. 1987. U.S. manufactured exports and export-related employment: Profiles of the 50

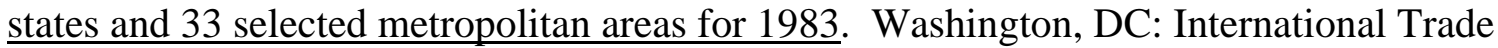
Administration, U.S. Department of Commerce.

Metropolitan Washington Airports Authority. 1994. Washington Dulles International Airport aircraft operations. Alexandria, VA: Office of Strategic Planning, Metropolitan Washington Airports Authority.

Meyer, E. 1946. Report of committee on site. In International Monetary Fund--Selected Documents, Board of Governors Inaugural Meeting, Savannah, Georgia, March 8 to 18, 1946. Eugene Meyer Papers, Library of Congress Manuscripts Collection, Box 86, Washington, D.C.

Moyers, B. 1971. Listening to America: A traveler rediscovers his country. New York: Harper and Row.

Muse, B. 1961. Virginia's massive resistance. Bloomington: Indiana Univ. Press.

Naylor, J. 1992. Business favors Washington first. Washington Times, 19 November, B:3.

New Bank Pleases Financiers. 1946. Washington Evening Star, 15 March, A:15.

Noyelle, T. J. 1985. Competition comes to town: Financial services in the Washington economy. Washington, DC: Greater Washington Research Center.

The 100 largest U.S. multinationals. 1993. Forbes Magazine, 152 (19 July): 182-86.

Parkinson, M. 1991. The rise of the entrepreneurial European city: Strategic responses to economic changes in the 1980s. Ekistics 58 (350-351): 299-307.

Portes, A., and A. Stepick. 1993. City on the edge: The transformation of Miami. Berkeley: Univ. of California Press.

Press, W. 1959. Letter to Jameson Parker, 23 March. Washington Board of Trade Papers, George Washington University Special Collections, Washington, D.C. 
Pressley, S. A. 1992. Multicultural D.C. area becoming multilingual. Washington Post, 11 February, A:1.

Ranking the Banks: Top Numbers 1992 Edition. 1992. New York: American Banker/Bond Buyer.

Reed, J. S. 1976. The heart of Dixie: An essay in folk geography. Social Forces 54 (4): 925-39. Reports say D.C. is a strong market, world-class city. 1989. National Real Estate Investor 31 (11): 32-37.

Reps, J. 1991. Washington on view: The nation's capital since 1790. Chapel Hill: Univ. of North Carolina Press.

Reston, J. 1941. L'Enfant's capital--and boomtown too. New York Times Magazine, 1 June, 67, 23.

Rhodes, H. 1920. American towns and people. New York: Robert McBride.

Ricci, D. 1993. The transformation of American politics: The new Washington and the rise of think tanks. New Haven, CT: Yale Univ. Press.

Rice, M. C., and P. L. Mason. 1966. Residence and migration of college students, fall 1963:

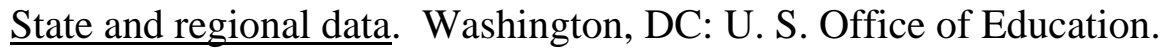

Robert R. Nathan Associates. 1978. Studies of the national government in the economy of the national capital region: International activities 1974. Washington, DC: National Capital Planning Commission.

Sands, D. 1988. Region mobilizes for growth in coming year. Washington Times, 25 January, C:1.

Sassen, S. 1991. The global city: New York, London, and Tokyo. Princeton, NJ: Princeton Univ. Press.

-----. 1994. Cities in a world economy. Thousand Oaks, CA: Pine Forge Press.

Sassen, S., and A. Portes. 1993. Miami: A new global city? Contemporary Sociology 22 (4): 
471-77.

Shaw, C. H., ed. 1956. Social list of Washington, D.C. Washington, DC: Author.

Shefter, M. 1993. New York's national and international influence. In Capital of the American century: The national and international influence of New York City, edited by M. Shefter, 1-25. New York: Russell Sage Foundation.

Shidler, A. 1980. Local community and national government. In Greater Washington in 1980, edited by A. Shidler, 1-27. Washington, DC: Greater Washington Research Center.

Singapore ranked top city for international headquarters. 1990. Daily Journal of Commerce (Portland), 10 September, 5.

Sister Cities International. 1991. Directory of sister cities, counties and states by state and country. Alexandria, VA: Author.

Sklair, L. 1991. Sociology of the global system: Social change in global perspective.

Baltimore, MD: Johns Hopkins Univ. Press.

Spayd, L. 1992. It's official: Washington-Baltimore. Washington Post, 29 December, A:1.

Stevens, W. O. 1943. Washington: The Cinderella city. New York: Dodd, Mead.

Strong, R. 1951. Residence and migration of college students, 1949-50. Washington, DC: U.S. Office of Education.

Thomas, A., and A. J. Thomas, Jr. 1963. The Organization of American States. Dallas:

Southern Methodist Univ. Press.

Tydings, J. R. 1978. Statement to Metropolitan Washington Savings and Loan League, 27 May. Washington Board of Trade papers, George Washington University Special Collections, Washington, D.C.

Union of International Associations, ed. 1985. Yearbook of international organizations, 1985/86. Vol. 2. Geographic volume. Munich: K. G. Saur Verlag.

Union of International Associations. 1962. Yearbook of international organizations, 1962-63. 
Brussels: Author.

U. S. Department of Commerce. 1993. Statistical abstract of the United States: 1993.

Washington, DC: Government Printing Office.

U.S. Department of State. 1992. Foreign Consular Offices in the United States. Washington, DC: Author.

U.S. House. 1977. Development of the nation's capital: Hearings before the Committee of the District of Columbia, House of Representatives, 95th Cong., 1st Sess., 24-25 May and 15, 18, 29-30 June, Serial No. 95-10.

U.S. Travel and Tourism Administration. 1991. User friendly facts: A resource book.

Washington, DC: U. S. Department of Commerce.

U.S. Bureau of the Census. 1990. 1990 census of population and housing: Summary social, economic and housing characteristics of the United States. Washington, DC: Government Printing Office.

Vance, J. E., Jr. 1977. This scene of man: The role and structure of the city in the geography of western civilization. New York: Harper.

Virginians seeking UNO site find Jim Crow law is barrier. 1946. Washington Star, 6 January, $\mathrm{A}: 10$.

Washington Board of Trade. 1945. Postwar Planning Committee in cooperation with the Committee for Economic Development. Population and business prospects for metropolitan Washington. Eugene Meyer Papers, Library of Congress Manuscripts Collection, Box 153, Washington, D.C.

-----. 1986. News 41 (12): 10-11A.

Washington Board of Trade Papers. 1959. Statements by Robert E. McLaughlin, Robert Wagner, Robert Moses, John W. Hanes, and Jacob Javits to President's Commission on the World's Fair. George Washington University Special Collections, Box 233, Washington, D.C. 
Washington Convention and Visitors Bureau. 1972. Conventions and meetings, Washington, D.C., 1972-81. Washington, DC: Author.

Washington, D.C., with its points of interest illustrated. 1894. New York: Mercantile Illustrating Co.

Washington Post retail memo and sales planner. 1984. 22 (2).

Weiss, J. 1990. Lobby fodder. Far Eastern Economic Review 148 (17): 24.

White, D., and T. Crimmins. 1978. How Atlanta grew: Cool heads, hot air, and hard work. Atlanta Economic Review 28 (1): 7-15.

Wiggins, S. P. 1966. The desegregation era in higher education. Berkeley, CA: McCutchan.

Zelinsky, W. 1980. America's vernacular regions. Annals of the Association of American Geographers 70 (1): 1-16.

-----. 1988. Nation into state: The shifting symbolic foundations of American nationalism. Chapel Hill: Univ. of North Carolina Press.

-----. 1990. Coming to America. American Demographics 12 (8): 44-47, 56.

Zukin, S. 1991. Landscapes of power. Berkeley: Univ. of California Press. 
Table 1

Geographically Identified Names of Washington Businesses and Organizations

\begin{tabular}{|c|c|c|c|}
\hline & National $^{\mathrm{a}}$ & Regional $^{\mathrm{b}}$ & International $^{\mathrm{C}}$ \\
\hline 1880 & 36 & 6 & 1 \\
\hline 1890 & 40 & 6 & 4 \\
\hline 1900 & 108 & 14 & 10 \\
\hline 1910 & 150 & 32 & 11 \\
\hline 1920 & 342 & 51 & 45 \\
\hline 1930 & 441 & 75 & 52 \\
\hline 1940 & 528 & 81 & 62 \\
\hline 1950 & 995 & 221 & 136 \\
\hline 1960 & 1194 & 237 & 189 \\
\hline 1970 & 1643 & 193 & 334 \\
\hline 1980 & 2108 & 212 & 493 \\
\hline 1991 & 4230 & 1260 & 845 \\
\hline
\end{tabular}

a. National: American, national, or nationwide

b. Regional: southern, south, southeast(ern), dixie, Atlantic, east(ern), east coast, middle- or mid-Atlantic, south Atlantic

c. International: global, world, international, inter-American, pan-American

Sources: 1880-1940, Washington City Directories; 1950, 1970, and 1980, telephone white pages: for the District of Columbia; 1960, telephone white pages for Washington Metropolitan Area; 1991, telephone white pages for Metropolitan Washington (some 1991 counts estimated from column inches). 
Table 2

Metropolitan Area Rankings on International Indicators

(rank among metropolitan areas with 1990 populations above 1 million ${ }^{\mathrm{a}}$ )

Category WASHINGTON NY CHICAGO BOSTON LA SF-0-SJ MIAMI ATLANTA HOUSTON

$\underline{\text { Foreign Markets }}$

Destination for foreign

$\begin{array}{lllllllll}6 & 1 & 7 & 8 & 2 & 3 & 5 & \text { na }\end{array}$

tourists (1988)

$\begin{array}{lllllllllll}\text { Manufacturing for Export } & \text { na } & 21 & 9 & 2 & 15 & 8 & 29 & 25 & 18 & \text { (employment/1000, }\end{array}$

1983)

Control Functions

$\begin{aligned} & \text { Diplomatic representation } \\ & \text { (1992) }\end{aligned}$
$\begin{aligned} & \text { International organizations } \\ & \text { (1986) }\end{aligned}$

\footnotetext{
a. LA: Los Angeles-Long Beach CMSA; SF-O-SJ: San Francisco-Oakland-San Jose CMSA

b. Tied with 21 other large and small cities with one each.
} 
Sources: U.S. Department of State 1992; Union of International Organizations 1985; U.S. Department of Commerce 1993; U.S.

Travel and Tourism Administration 1991; U.S. Bureau of the Census 1990, table 1; Ranking the Banks: Top Numbers 1992

Edition 1992; "The 100 largest U.S. multinationals" 1993; Sister Cities International 1991; Mehl 1987. 